\title{
Screening of Hepatitis B Surface Antigen and Hepatitis C Antibody in Pre-Operative Patients in a Tertiary Care Hospital in Kanyakumari District, India
}

\author{
V.R. Vidhya* \\ Department of Microbiology, Sree Mookambika Institute of Medical Sciences, \\ Kulasekharam, K.K. Dist, Tamilnadu-629161, India \\ *Corresponding author
}

Keywords

Hepatitis B surface antigen, Hepatitis C antibody, ELISA

Article Info

Accepted:

15 December 2018

Available Online:

10 January 2019

\section{A B S T R A C T}

The term viral hepatitis refers to primary infection of liver by any one of the heterogeneous group of hepatitis virus which currently consists of types A, B, C, D, E and G Hepatitis virus infection occurs as an acute illness. HBsAg (Hepatitis B surface antigen) is the most common marker of infection, which is present in high concentrations in early acute infections and is continued to be produced in chronic disease. The present study is undertaken because there is paucity of data indicating prevalence of Hepatitis B and Hepatitis C among pre-operative patients admitted in our hospital. Data is collected from the records available in the serology section of Microbiology Department in the Central Lab of Sree Mookambika Institute of Medical Sciences, kulasekaram, Kanyakumari District, Tamil Nadu. 600 serum samples of the preoperative patients admitted in this institution were received in the serology section during a period of six months from May 2018. These samples were analysed for HBsAg antigen and hepatitis C antibody (HCV). All samples were subjected to immunochromatographic test and positives were confirmed by ELISA. Out of the 600 serum samples collected, 15 samples were found to be positive for HBsAg. None of the samples were positive for hepatitis $\mathrm{C}$ antibody. Out of the 15 patients positive for HBsAg, 4 (26.6\%) had history of previous surgery, $3(20 \%)$ patients had history of previous blood transfusions and $3(20 \%)$ had history of previous dental procedures. In our hospital the 15 patients $(2.5 \%)$ out of 600 pre-operative patients were positive for Hepatitis B surface antigen. None of the patients were positive for Hepatitis C antibody.

\section{Introduction}

Hepatitis B virus is a partially double stranded circular DNA virus and is a member of Hepadnaviridae family. The family consists of a core capsid which consists of viral DNA and this is surrounded by a viral envelope containing surface antigen $\mathrm{HBsAg}^{2}$. The HBsAg particle vary greatly in morphology and are found in high concentrations in early acute infections and is continued to be produced in chronic disease ${ }^{3}$. World wide over 2 billion people have been infected with HBV infection and more than 350 million have chronic HBV infection. In India the prevalence rate of Hepatitis $B$ virus infection is about $2 \%$ to $7 \%^{4}$ 
Hepatitis B virus infection occurs as an acute illness of about 2 weeks to 3 months with an incubation period of about 4 weeks to 12 weeks. Natural infection occurs only in humans. HBsAg is the most commonly used marker of infection. An individual positive for HBsAg is considered to be infected with HBV and is therefore potentially infectious. This infection occurs most commonly in young adults through the use of contaminated syringes and needles, through unprotected sexual practices, perinatally from mother to baby and also through the use of infected blood and blood products ${ }^{5}$.

Hepatitis C virus infection is seen only in humans. Epidemiology of $\mathrm{HCV}$ resembles hepatitis B virus infection ${ }^{6}$. In India antibodies to Hepatitis $\mathrm{C}$ virus are present in approximately 15 million people with prevalence rate of $2 \%$. Infection is mainly by blood transfusion. Hepatitis $\mathrm{C}$ virus has a single stranded RNA genome, enclosed within a core and surrounded by an envelope carrying glycoprotein spikes ${ }^{7}$.

Both these infections can be transmitted through blood and body fluids, tattooing, through infected instruments, unsafe shave by barbers and through sexual contact ${ }^{8}$. Medical personals are most susceptible to this infection.

There should be proper preventive measures to prevent its spread in the community. Unfortunately, once infected, these infections show poor response to the available treatment modalities ${ }^{9}$. Therefore precautionary methods are considered the best way to avoid spreading the disease.

Unlike HCV, several vaccines have been developed for $\mathrm{HBV}$ that provide long lasting immunity to the individual. Both infections can be further avoided by use of disposable syringes, screened blood transfusion, avoidance of sexual abuse, antiseptic shaving and use of proper antiseptic measures in the hospitals, and clinics ${ }^{10}$.

\section{Materials and Methods}

The study was conducted after receiving consent from Instituitional Research and Ethical committee. The study had been conducted for a period of six months from $1^{\text {st }}$ May 2018 to $31^{\text {st }}$ October 2018.

This is a cross-sectional study based on the data collected from the records in the Microbiology division of the Central Lab of Sree Mookambika Institute of Medical Sciences, Kulasekharam, Kanyakumari District. The predisposing factors like history of previous surgery, previous blood transfusions, any dental procedures in the past, any abroad visit, any positive family history were elicited from the history given by the clinician.

\section{Inclusion criteria}

All the pre-operative patients from the various departments (Surgery, Orthopaedics, Paediatrics, Obstetrics and Gyanecology, ENT, Ophthalmology, Cardiology, Urology, Neurosurgery etc) admitted in this institution from $1^{\text {st }}$ May to $31^{\text {st }}$ October were analysed.

\section{Exclusion critera: Nil.}

\section{Parameters that were analysed in the study}

1) Hepatitis B surface antigen (HBsAg)

2) Antibodies to Hepatitis $\mathrm{C}$ virus (HCV) Sample size; 600

Scientific basis of the sample size used in the study

By literature reference, (Epidemiology of hepatitis $\mathrm{B}$ virus infection in India) by $\mathrm{BN}$ 
Tandon, SK Acharya, A Tandon, The prevalence of hepatitis B infection among the pre-operative patients is $14 \%{ }^{1}$.

$\mathrm{P}=14, \quad \mathrm{q}=100-\mathrm{p}=100-14=86, \mathrm{~d}=20 \%$ of $\mathrm{p}$ $=20 / 100 \times 14=2.8$

Sample size $=4 \mathrm{pq} / \mathrm{d}^{2}=4 \times 14 \times 86 /(2.8)^{2}=614$. But during the period of six month study only 600 samples were analysed in the Central lab.

\section{Results and Discussion}

Out of the 600 serum samples analysed, 15 samples had shown positivity for HBsAg that is $2.5 \%$ patients were positive for $\mathrm{HBsAg}$. Out of the $15 \mathrm{HBsAg}$ positive patients, 4 (26.6\%) had history of previous surgery, 3 $(20 \%)$ had history of previous blood transfusion and 3 (20\%) had history of previous dental procedures.

Table.1 Patients positive for HBsAg and antibodies to HCV are given below in the form of table

\begin{tabular}{|l|l|l|l|}
\hline PARAMETERS & POSITIVE & NEGATIVE & TOTAL \\
\hline HBsAg antigen & $15(2.5 \%)$ & $585(97.5 \%)$ & 600 \\
\hline Antibody to HCV & $0 \%$ & $600(100 \%)$ & 600 \\
\hline
\end{tabular}

Table.2 Predisposing factors for hepatitis B among the 15 positive patients

\begin{tabular}{|l|l|l|}
\hline FACTORS & NUMBER & PERCENTAGE \\
\hline Previous surgery & 4 & $26.6 \%$ \\
\hline $\begin{array}{l}\text { Previous blood } \\
\text { transfusion }\end{array}$ & 3 & $20 \%$ \\
\hline Dental procedures & 3 & $20 \%$ \\
\hline No known factor & 5 & $33.3 \%$ \\
\hline TOTAL & 15 & 100 \\
\hline
\end{tabular}

Fig.1 The pie-diagram shows that 2.5\% (15/600) were HBsAg positive

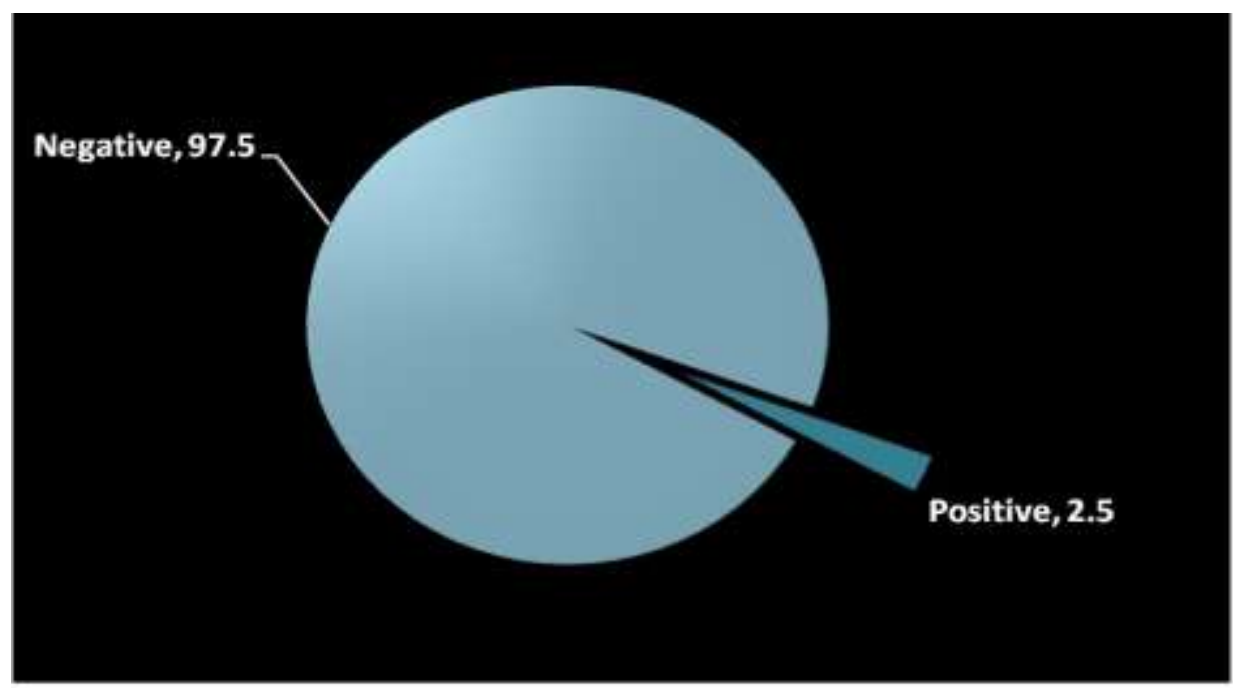


Hepatitis B virus and Hepatitis C virus account for substantial proportion of liver diseases world wide. These viruses are responsible for liver damages ranging from minor disorders to liver cirrhosis and hepatocellular carcinomas ${ }^{6}$. This study was planned to evaluate the prevalence of Hepatitis B and Hepatitis C among the patients who were admitted for various surgeries in this institute for a period of 6 months. A total of 600 pre-operative patients were screened for Hepatitis B surface antigen and antibody to Hepatitis C virus. Only 15 patients 600 were found to be positive for HBsAg. Therefore the positivity rate for HBsAg among the pre-operative patients is found to be $2.5 \%$. None of them were found to be positive for antibodies to $\mathrm{HCV}$.

Tandon et al., in 2014 had conducted a study on the epidemiology of hepatitis B virus infection in India. In India, hepatitis B antigen positivity rate is $14 \%$.

Blood transfusions represent the most important route of HBV transmission. $\mathrm{HBV}$ is reported to be responsible for $70 \%$ of cases of chronic hepatitis and $80 \%$ of cases of cirrhosis of liver. He concluded that hepatitis $\mathrm{B}$ is a major public health problem in India and will continue to be until appropriate nation wide vaccination programmes and other control measures are available ${ }^{1}$.

In the present study the past history of 15 Hepatitis B positive patients were analysed for any predisposing factors. 4 (26.6\%) had history of previous surgeries in the past, $3(20 \%)$ patients had history of blood transfusions in the past and $3(20 \%)$ patients history of some dental procedures in the past. In 5 patients no significant predisposing factors were noticed.

Muhammed et al., in 2007 studied the prevalence of Hepatitis B and Hepatitis C in
Orthopaedics patients at Ayub Teaching Hospital, Abbottabad. According to this study the predisposing factors of Hepatitis B were previous history of surgery in $21 \%$ patients, blood transfusion history in $16 \%$ patients, dental procedures in $8.3 \%$ patients ${ }^{11}$.

Screening for $\mathrm{HBV}, \mathrm{HCV}$ as a part of routine pre-operative investigation is a common practise in many centres. The investigations are done to prevent transmission from patients to health care workers, to take adequate precautions in the form of enhanced personal protective equipments (PPE) during the surgical procedures, to decide on the sequence and placement of the patient in a surgical list and to decide on the nature of equipment and environmental decontamination following the procedure $^{12}$.

Therefore we can conclude that all patients who need surgery including dental procedures should be routinely screened for Hepatitis B and $\mathrm{C}$. There should be separate operation theatres facilities for these patients. If found to be positive extreme care should be taken to enforce preventive measures.

\section{References}

Tandon B N, Achary S K, Tandon A. Epidemilogy of hepatitis $\mathrm{B}$ virus infection in India. J Virol 1999; 100: 157-60.

Jamil M, Khan M S, Sultan S, Zardad S, Jan S, Sahibzada A S, et al., Prevalence of Hepatitis B and C in orthopaedic patients at Ayub Teaching Hospital, Abbottabad. J Ayub Med Coll 2003; 19(4):1-4.

Choudhary I A, Khan S A, Samiullah. Should we do hepatitis B and C screening for each patient before surgery. Pak $\mathbf{J}$ Med Sci 2005:21(3):159-79.

Seeger C, Mason S. Hepatitis B virus biology. Microbiol Mol Biol Rev 2000;64:71-4. 
Acharya S K, Madan K, Dattagupta S. Viral hepatitis in India. Natl Med J India, 2006;19(4):203-18.

Khokar M S, Gill G L. General seroprevalance of hepatitis $\mathrm{B}$ and $\mathrm{C}$ in India. J Coll Phy Surg Pak 2004; 2(2): 389-93.

Talpur A A, Ansari A G. Prevalance of hepatitis $\mathrm{B}$ and $\mathrm{C}$ in surgical patients. Indian J Med Microbiol 2007; 25(3): 168-72.

Loui Z, Bare B, Laraba A. Hepatitis B and Hepatitis $\mathrm{C}$ virus dual infection. Int $\mathbf{J}$ Med Sci 2012; 17(5): 1132-6.

Baveja CP. Microscopy and Morphology of Bacteria. In: Baveja CP. Textbook of Microbiology. $3^{\text {rd }}$ ed. New Delhi: Gupta
V, Gupta D; 2009. p. 491-96.

Choudhry A, Santra S. Hepatitis C virus infection in general population in West Bengal. Indian J Med Microbiol 2003; 22(3):802-9.

Muhammed K, Muhammed Jamil, Sakhi Jan, Shoaib Zardad. Prevalence of Hepatitis $\mathrm{B}$ and $\mathrm{C}$ in orthopaedics patients at Ayub Teaching Hospital, Abbottabad. J Ayub Med Coll Abbottabad 2007; 19(4): 82-6.

$\mathrm{R}$ Ahmed, $\mathrm{S}$ Bhattacharya. Universal screening versus universal precautions in the context of pre-operative screening for HIV, HBV, HCV in India. Indian J Med Microbiol 2013; 31(3): 219-25.

\section{How to cite this article:}

Vidhya, V.R. 2019. Screening of Hepatitis B Surface Antigen and Hepatitis C Antibody in PreOperative Patients in a Tertiary Care Hospital in Kanyakumari District, India. Int.J.Curr.Microbiol.App.Sci. 8(01): 2312-2316. doi: https://doi.org/10.20546/ijcmas.2019.801.242 